\title{
Será que os novos movimentos e comunidades eclesiais são expressão da Igreja local?
}

\author{
Orientador: Prof ${ }^{a}$ Ana Maria Tepedino
}

Pesquisador: Mozart Nunes de Andrade Santos Neto

\section{Fonte: CNPq}

\section{Introdução}

O presente projeto de estudo e pesquisa tem como indagação: Será que os Novos Movimentos Eclesiais e Novas Comunidades são expressão da Igreja Local? Trata-se de uma pesquisa empolgante sobre as abordagens feitas até o presente momento acerca dos Novos Movimentos Eclesiais e das Novas Comunidades; as quais surgem no campo eclesial pós moderno com tamanha proporção e pujança, como formas de expressar e manifestar a "graça" carismática da Igreja.

Ao buscar compreender as características da Igreja Local com suas expressões, percebe-se que algo novo começou a surgir no seio eclesial - um "Vinho Novo". Esta ação vem pela força transformadora do Espírito de Deus clamado desde o Concilio Vaticano II pelas lideranças eclesiásticas.

\section{Objetivos}

O presente trabalho de pesquisa tem como objetivo aprofundar o estudo sobre as abordagens feitas acerca dos Novos Movimentos Eclesiais e Novas Comunidades que afloram no campo eclesial local com suas formas de expressar e manifestar a "graça" carismática da Igreja. Importante ressaltar que o enfoque sobre os Novos Movimentos Eclesiais e Novas Comunidades será quanto à questão se são eles expressões da Igreja Local. Faz-se necessário usar alguns fundamentos bíblico-teológicos da mensagem eclesiológica e pastoral para responder às "necessidades carismáticas" do povo em vista da vivência de sua vocação como Eclésia de comunhão. 